\title{
Postoperativ smerte - undervurdert og underbehandlet
}

Hvert år blir omtrent én av ti nordmenn operert. Kirurgi innebærer skade av vev og nervetråder, men den naturgitte smerten etterpå er uhensiktsmessig. Ekstra smerte knyttet til varsling av postoperative komplikasjoner vil som oftest bryte gjennom god smertelindring uansett og vil dessuten være ledsaget av andre og mer pålitelige kliniske tegn.

Fredheim og medarbeidere viser i dette nummer av Tidsskriftet at smertelindringen er utilstrekkelig hos så mange som $38 \%$ av voksne innlagte nyopererte (1). Dette skyldes både at smerte blir for dårlig registrert og dokumentert, og at tilgjengelige medikamenter og metoder ikke brukes optimalt. Registrering og dokumentasjon av smerteintensiteten bør være like naturlig som å registrere eksempelvis pulsfrekvens, blodtrykk, kroppstemperatur og naturlige funksjoner. Vårt gamle visittmantra «hvordan har vi det i dag?» er definitivt ikke godt nok. Pasienter må observeres og utspørres spesifikt om smerte slik at man får tak i forekomst, intensitet, varighet og utløsende eller lindrende faktorer.

Hovedproblemet i smertebehandlingen, som omtales i en annen artikkel av de samme forfatterne (2), er å avveie risiko og bivirkninger mot nytte. Nytten, dvs. smertelindringen, anses som noe subjektivt og uspesifikt, mens redselen for meget sjeldne, men objektive og alvorlige komplikasjoner kan bli for stor. Dette leder ofte til underbehandling. Multimodal behandling anbefales - dvs. bruk av mange forskjellige metoder som alle bidrar med smertelindring uten å øke risikoen for bivirkninger tilsvarende. Et viktig mål er mindre bruk og lavere dosering av opioider, bl.a. fordi disse hyppig gir tretthet, kvalme, obstipasjon, søvnforstyrrelser og ev. risiko for respirasjonsdepresjon. Ett eksempel er nyopererte brystkreftpasienter som fikk en kombinasjon av paracetamol, ikkesteroide antiinflammatoriske midler (NSAID) av COX-2-hemmertype, glukokortikoid og lokalanestesi. Hele $40 \%$ anga at de var helt fri for smerte de tre første dagene - uten opioider (3). Vi må imidlertid være forberedt på å bruke opioider når det trengs.

Forskning på postoperativ smerte dreier seg særlig om fire spørsmål knyttet til pasienter der vi ikke lykkes: Kan vi bli bedre på å justere utvalget av multimodale komponenter tilpasset den enkelte type inngrep? Kan vi ta i bruk enda flere medikamenter og metoder? Kan vi forutsi hvilke pasienter som får mye postoperativ smerte? Kan vi forebygge kronisk smerte? Per i dag vet vi at genetiske forhold og psykososiale faktorer er viktige faktorer når det gjelder postoperativ smerte, medikamenteffekter og ev. utvikling av kronisk smerte (4). Likeledes vet vi at smertetilstander før operasjonen, enten knyttet til aktuelle lidelse eller andre lidelser, har betydning. I fremtiden kan vi tenke oss bedre skåringssystemer for å kunne forutsi hvilke pasienter som får særlig plagsomme smerter.

Begge artiklene til Fredheim og medarbeidere omhandler kirurgi hos voksne innlagte. I Norge gjøres i dag mer enn $50 \%$ av alle inngrep som dagkirurgi, og det er god grunn til å tro at forholdene her er litt annerledes. Blant annet vil NSAID-midler, herunder COX-2-hemmere, bli brukt hos de fleste (5), og vekten på peroral behandling vil nødvendigvis bli sterkere (6). Like etter store operasjoner vil man i en del tilfeller være redd for blødninger og ustabil sirkulasjon og således ikke ønske å bruke potensielt nyretoksiske NSAID-midler, selv om ev. nyresvikt oftest vil være reversibel. I stedet vil titrert, intravenøst opioid i nødvendige og ofte store doser oppleves som trygt, fordi man på en postoperativ overvåkingsavdeling raskt kan gripe inn ved begynnende respirasjonsdepresjon. Denne avveiningen bør være annerledes når pasienten er kommet i stabil sirkulatorisk fase på en sengepost eller er sendt hjem. Redsel for forsinket beintilheling etter ortopedisk kirurgi, noe som er godt dokumentert hos forsøksdyr, men ikke hos mennesker (7), kan også resultere $\mathrm{i}$ at pasienter ikke făr NSAIDmidler. Det kan synes som om den marginale risikoen for NSAIDbivirkninger ved korttidsbehandling er overdrevet og fører til økt bruk av opioider - og i verste fall til alvorlige bivirkninger av dette. Vi har i Norge i den senere tid hatt flere medieomtalte dødsfall og nestendødsfall på sengepost hos nyopererte. De fikk store doser opioider under mangelfullt tilsyn og svært lite ikke-opioide midler (8).

Svaret på dette er ikke å la pasientene ligge med smerte, men å lage gode rutiner for optimal ikke-opiod smertelindring. Om nødvendig skal man absolutt supplere med opioder på toppen, men i titrerte doser, til man oppnår effekt - og under adekvat overvåking. Et hjelpemiddel her kan være ny trådløs teknologi som muliggjør overvåking av pustefunksjon og oksygenmetning hos dem som ligger alene på vanlig sengepost (9).

Vi har en jobb å gjøre for pasienter som har smerter etter en operasjon. Vi har kunnskap og godt verktøy tilgjengelig. Mye kan gjøres ved simpelthen å erkjenne og implementere dette. Gode basisrutiner bør tilpasses forholdene på det enkelte sykehus, det aktuelle inngrep og den enkelte pasient.

\section{Johan Ræder}

johan.rader@medisin.uio.no

Johan Ræder (f. 1954) er seksjonsoverlege ved Avdeling for anestesiologi ved Oslo universitetssykehus, Ullevål, og professor II ved Det medisinske fakultet, Universitetet i Oslo.

Ingen oppgitte interessekonflikter.

\section{Litteratur}

. Fredheim OMS, Kvarstein G, Undall E et al. Postoperativ smerte hos pasienter innlagt i norske sykehus. Tidsskr Nor Legeforen 2011: 131: 1763-7.

2. Fredheim OMS, Borchgrevink PC, Kvarstein G. Behandling av postoperativ smerte i sykehus. Tidsskr Nor Legeforen 2011; 131: 1772-6.

3. Hval K, Thagaard KS, Schlichting E et al. The prolonged postoperative analgesic effect when dexamethasone is added to a nonsteroidal antiinflammatory drug (rofecoxib) before breast surgery. Anesth Analg 2007; 105: 481-6.

4. Werner MU, Mjobo HN, Nielsen PR et al. Prediction of postoperative pain: a systematic review of predictive experimental pain studies. Anesthesiology 2010; 112: $1494-502$

5. Segerdahl M, Warren-Stomberg M, Rawal N et al. Clinical practice and routines for day surgery in Sweden: results from a nation-wide survey. Acta Anaesthesiol Scand 2008; 52: 117-24.

6. Ræder J. Postoperative pain. I: Ræder J, red. Clinical ambulatory anesthesia Cambridge: Cambridge University Press, 2011: 106-36.

7. Dodwell ER, Latorre JG. Parisini E et al. NSAID exposure and risk of nonunion: a meta-analysis of case-control and cohort studies. Calcif Tissue Int 2010; 87: $193-202$.

8. Vestre Viken vedtar bot på 500.000 kroner. Aftenposten 7.5.2010. www.aftenposten no/nyheter/iriks/article3642371 ece (29.8.2011).

Taenzer AH, Pyke JB, McGrath SP et al. Impact of pulse oximetry surveillance on rescue events and intensive care unit transfers: a before-and-after concurrence study. Anesthesiology 2010; 112: 282-7.

Engelsk oversettelse av hele artikkelen på www.tidsskriftet.no 